\author{
PAWEŁ GACEK \\ ORCID: 0000-0001-6365-3146
}

DOI: $10.4467 / 20801335$ PBW.21.005.13562

\title{
Zakaz członkostwa w partii politycznej funkcjonariusza Agencji Bezpieczeństwa Wewnętrznego i Agencji Wywiadu oraz uczestnictwa $w$ działalności tej partii lub na jej rzecz
}

\section{Zagadnienia wstępne. Szczególny charakter służby publicznej}

Służba publiczna ma charakter selekcyjny. To oznacza, że nie każdy, kto się ubiega o przyjęcie do niej, musi zostać przyjęty. Wszystkie formacje zmilitaryzowane (paramilitarne) odrębnie określają wymogi, których spełnienie umożliwia nawiązanie więzi prawnej z kandydatem do służby, tj. stosunku służbowego ${ }^{1}$. Również w art. 44 Ustawy $z$ dnia 24 maja 2002 r. o Agencji Bezpieczeństwa Wewnętrznego oraz Agencji Wywia$d u^{2}$ (dalej: ustawa o ABW oraz AW) enumeratywnie zostały wskazane cechy, jakimi powinna legitymować się osoba fizyczna zgłaszająca gotowość podjęcia służby w tych formacjach ${ }^{3}$. Jedną $\mathrm{z}$ nich jest warunek wymieniony w art. 44 pkt 5 ustawy o ABW oraz $\mathrm{AW}^{4}$. Kandydat do służby musi być gotowy do poddania się szczególnego rodzaju

1 Szerzej na temat stosunku służbowego zob. T. Kuczyński, E. Mazurczak-Jasińska, J. Stelina, Stosunek służbowy, w: System prawa administracyjnego, t. 11, R. Hauser, Z. Niewiadomski, A. Wróbel (red.), Warszawa 2011; P. Szustakiewicz, Stosunki służbowe funkcjonariuszy stużb mundurowych i żotnierzy zawodowych jako sprawa administracyjna, Warszawa 2012; M. Wieczorek, Charakter prawny stosunków stużbowych funkcjonariuszy służb mundurowych, Toruń 2017; także: P. Gacek, Nawiązanie stosunku służbowego z funkcjonariuszem Agencji Bezpieczeństwa Wewnętrznego i Agencji Wywiadu. Charakter prawny mianowania - wybrane aspekty, „Przegląd Bezpieczeństwa Wewnętrznego" 2020, nr 22, s. 98 i nast., i przywołana tam literatura.

2 Tekst jednolity: DzU z 2020 r. poz. 27, ze zm.

3 Szerzej na ten temat zob. P. Gacek, Wymogi formalne niezbędne do petnienia służby w Agencji Bezpieczeństwa Wewnętrznego i Agencji Wywiadu - wybrane aspekty, „Przegląd Bezpieczeństwa Wewnętrznego" 2017, nr 17, s. 56 i nast.

4 Zgodnie z tym przepisem służbę w ABW albo AW może pełnić osoba mająca wykształcenie co najmniej średnie lub średnie branżowe i określone kwalifikacje zawodowe oraz zdolność fizyczną 
reżimowi obowiązującemu w tego typu formacjach. Musi zatem mieć świadomość, że służba publiczna wiąże się ze szczególnymi i specyficznymi ograniczeniami nieznanymi innym grupom zawodowym, których podstawą zatrudnienia jest stosunek pracy. Służba nie jest bowiem zwykłą pracą najemną. Nie stanowi więc stosunku pracy. Stosunek służbowy jest usytuowany w sferze prawa administracyjnego. Jego kształt jest stricte administracyjnoprawny, z czego wynika, że jego ramy w sposób jednostronny i władczy określa organ administracyjny. Nie oznacza to jednak możliwości uregulowania go w sposób dowolny, gdyż poszczególne elementy kształtujące ten stosunek wynikają wprost $\mathrm{z}$ konkretnych przepisów pragmatyki służbowej. Podmiot zatrudniający (o którym mowa w art. 50 ust. 1 ustawy o ABW oraz AW, tj. Szef ABW lub Szef AW) nie może więc arbitralnie określić warunków służby funkcjonariusza, z którym nawiązuje stosunek służbowy. Kandydat do służby nie uczestniczy z kolei w kształtowaniu powstałej z nim więzi prawnej. Może przyjąć w całości zaproponowane warunki lub je odrzucić. Nie może ich negocjować, ponieważ stosunek służbowy nie jest stosunkiem obligacyjnym, którego kształt jest określany w drodze zgodnych oświadczeń woli stron tego stosunku. Nawiązanie stosunku służbowego musi poprzedzać dobrowolne zgłoszenie się osoby fizycznej (kandydata) do służby. Jak słusznie zauważa Przemysław Szustakiewicz, do służby w ABW lub AW (a także do innych formacji zmilitaryzowanych lub paramilitarnych) nie można zostać „wcielonym”. Kandydat zgłaszający gotowość do podjęcia służby w formacji zmilitaryzowanej (paramilitarnej) jest zobligowany przede wszystkim do wykazania woli poddania się jej rygorom ${ }^{5}$. Dobrowolność jest podstawowym wymogiem pełnienia służby. Tym samym oświadczenie kandydata o dobrowolnym zgłoszeniu się do służby musi immanentnie łączyć się z dobrowolnym oświadczeniem, z którego wynika, że jest on gotów poddać się rygorom tej służby. Zatem musi on wykazać się aktywnością, która w ocenie podmiotu zatrudniającego będzie mogła być uznana za spełnienie tego podstawowego wymogu. Z kolei spełnienie wymogów wskazanych w art. 44 ustawy o ABW oraz AW stanowi nie tylko warunek wstępny, umożliwiający nawiązanie stosunku służbowego, lecz także jest niezbędne do jego kontynuowania przez funkcjonariuszy ABW i AW. Konieczne jest więc zaakcentowanie, że warunki, o których mowa, dotyczą zarówno kandydatów do służby, jak i czynnych funkcjonariuszy ABW i AW.

Istnieją jednak jeszcze inne uwarunkowania (obowiązki, nakazy i zakazy), które zaczynają obowiązywać w związku z nawiązaniem stosunku służbowego. Odnoszą się one wyłącznie do funkcjonariuszy ABW oraz AW i wytyczają sferę ich dozwolonego zachowania jako funkcjonariuszy publicznych i członków formacji zhierarchizowanych i zmilitaryzowanych. Nie są one badane w trakcie trwającego postępowania

i psychiczną do służby w formacjach uzbrojonych, wymagających szczególnej dyscypliny służbowej, której taka osoba jest gotowa się podporządkować.

5 B. Opaliński, M. Rogalski, P. Szustakiewicz, Ustawa o Agencji Bezpieczeństwa Wewnętrznego oraz Agencji Wywiadu. Komentarz, Warszawa 2017, Legalis (komentarz do art. 48 ustawy o ABW oraz AW). 
kwalifikacyjnego, gdyż nie dotyczą kandydatów do służby. Materializują się z kolei w momencie, gdy osoba fizyczna nabywa status funkcjonariusza. Ich przestrzeganie jest świadectwem dobrowolnego podporządkowania się, przestrzegania dyscypliny służbowej i - w szerszym aspekcie - zdolności funkcjonariusza do poddania się reżimowi wynikającemu z charakteru pełnionej służby. Dobrowolność jest podstawą stosunku służbowego.

Funkcjonariusze ABW oraz AW nie mogą m.in. podejmować określonej działalności (art. 79a ustawy o ABW oraz AW) ani zajęcia zarobkowego poza służbą bez zgody przełożonego (art. 80 ustawy o ABW oraz AW), są zobowiązani do składania oświadczeń majątkowych (art. 80a ustawy o ABW oraz AW), nie mogą być członkami partii politycznych ani uczestniczyć w działalności partii lub na jej rzecz, nie mogą się zrzeszać w związkach zawodowych, są obowiązani do poinformowania przełożonego o przynależności do stowarzyszeń krajowych, do uzyskania zezwolenia szefa właściwej Agencji lub upoważnionego przez niego przełożonego na przynależność do organizacji lub stowarzyszeń zagranicznych albo międzynarodowych (art. 81 ustawy o ABW oraz AW), a także do uzyskania zezwolenia szefa właściwej Agencji na wyjazd za granicę (art. 82 ustawy o ABW oraz AW). Te ograniczenia mają na celu zagwarantowanie ochrony dobra publicznego, a tym samym - przyznania mu prymatu przed partykularnym interesem samego funkcjonariusza ${ }^{6}$.

Rezygnacja z poszczególnych wolności i praw musi być poprzedzona dobrowolną zgodą funkcjonariusza, który uprzednio dobrowolnie zgłosił gotowość pełnienia służby, a następnie przyjął akt mianowania inicjujący stosunek służbowy. Ustanowione zakazy wynikają z charakteru służby w formacjach, jakimi są ABW i AW. Funkcjonariusz może się nie podporządkować wymienionym ograniczeniom lub zakazom, ale takie działanie może skutkować jego odpowiedzialnością dyscyplinarną za naruszenie dyscypliny służbowej (art. 145 ust. 1 ustawy o ABW oraz AW) 7 . Może to również doprowadzić do rozwiązania z nim stosunku służbowego, szczególnie na podstawie art. 60 ust. 2 pkt 5 ustawy o ABW oraz $\mathrm{AW}^{8}$. Świadome i celowe naruszenie norm zawartych w przepisach powszechnie obowiązujących (zawartych w ustawie o ABW oraz AW) mogłoby świadczyć w sposób bezpośredni o braku zgody funkcjonariusza na poddanie się

6 B. Opaliński, P. Szustakiewicz, Agencja Bezpieczeństwa Wewnętrznego i Agencja Wywiadu, w: Stosunek stużbowy w formacjach mundurowych, W. Maciejko, P. Szustakiewicz (red.), Warszawa 2016, Legalis/el.

7 Jak słusznie zauważa się w judykaturze, w ramach postępowania dyscyplinarnego rozstrzyga się o odpowiedzialności funkcjonariusza za czyny, które uchybiają godności lub regułom wykonywania zawodu. Nie muszą one jednak wyczerpywać jednocześnie znamion przestępstw lub wykroczeń (wyrok Naczelnego Sądu Administracyjnego, dalej: NSA, z 5 V 2011 r., I OSK 53/11, Legalis nr 352235).

8 Nie można również wykluczyć, że naruszenie art. 81 ust. 1 ustawy o ABW oraz AW, będące podstawą do zainicjowania postępowania dyscyplinarnego, mogłoby skutkować wymierzeniem funkcjonariuszowi kary dyscyplinarnej wydalenia ze służby (art. 146 ust. 1 pkt 10 ustawy o ABW oraz AW). Wówczas jednak zmaterializowałaby się przesłanka do obligatoryjnego zwolnienia ze służby na podstawie art. 60 ust. 1 pkt 3 wymienionej ustawy). 
szczególnemu rygorowi pełnienia służby i reżimowi panującemu $\mathrm{w}$ formacji zhierarchizowanej i zmilitaryzowanej. Takie zachowanie mogłoby, w ocenie jego przełożonego, być podstawą uznania, że została naruszona wartość prawnie chroniona, jaką jest „ważny interes służby”. Pojęcie ważny interes służby stanowi klauzulę generalną ale nie może budzić wątpliwości, że takie pojęcia, jak interes służby czy dobro służby są tożsame z pojęciem interes społeczny. Ustawodawca uzasadnił taką podstawę zwolnienia funkcjonariusza ze służby potrzebą ochrony interesu służby (interesu społecznego) jako interesu nadrzędnego w stosunku do partykularnego interesu jednostki ${ }^{10}$. Jak słusznie zauważa Naczelny Sąd Administracyjny w wyroku z 8 czerwca 2017 r., I OSK 656/16 ${ }^{11}$ :

Ze służbą w Policji łączą się nie tylko liczne przywileje, ale także istotne obowiązki, a nawet pewne ograniczenia wolności osobistej. Każdy funkcjonariusz[,] decydując się na dobrowolne przystąpienie do takiej służby, musi mieć tego świadomość. Składa on rotę ślubowania i zobowiązuje się do respektowania reguł obowiązujących w macierzystej formacji, w tym do dbałości o honor, godność i dobre imię służby i do przestrzegania zasad etyki zawodowej. Osoba mianowana na stanowisko funkcjonariusza Policji w czasie wolnym od zajęć służbowych nie przestaje być policjantem. Zatem żaden funkcjonariusz Policji nie jest zwolniony z należytego zachowania się nawet $\mathrm{w}$ czasie wolnym od służby. Musi on zawsze postępować tak, by swą postawą umacniać autorytet i zaufanie Policji, a ponadto bezwzględnie unikać wszystkich takich sytuacji, które godziłyby w dobre imię macierzystej formacji. Powinien być on ponadto gotowym do niesienia pomocy innym osobom, które w różnych okolicznościach mogą potrzebować takiego wsparcia.

Chociaż przywołane orzeczenie dotyczy funkcjonariusza Policji, to nie ulega wątpliwości, że stanowisko w nim wyrażone można odnieść per analogiam do funkcjonariuszy ABW i AW. Służba $w$ formacji zmilitaryzowanej i zhierarchizowanej obliguje bowiem do określonego sposobu postępowania, zachowania zgodnego z określonymi nakazami i zakazami, wynikającymi zarówno z przepisów prawa powszechnie obowiązującego, przepisów wewnętrznych, jak i rozkazów i poleceń przełożonych. W interesie służby (lub szerszej - w interesie społecznym) jest, aby funkcjonariusze podporządkowali się regułom panującym w organizacji mającej strukturę zhierarchizowaną.

\footnotetext{
9 Nie jest to (czyli „ważny interes służby”) pojęcie prawnie zdefiniowane. W orzecznictwie przyjmuje się jednak, że przy odczytywaniu treści wyrażenia „ważny interes służby” należy sięgnąć przede wszystkim do przepisów regulujących cele i zadania danej formacji (w tym przypadku orzeczenie dotyczyło funkcjonariusza Policji) oraz szczególnego statusu funkcjonariuszy w niej zatrudnionych (wyrok NSA z 4 VIII 2017 r., I OSK 1607/16, Legalis nr 1664019), podobnie w wyroku NSA z 29 I 2020 r., I OSK 3250/18, Legalis nr 2286751 oraz w wyroku NSA z 18 V 2018 r., I OSK 2439/16, Legalis nr 1837307.

10 Wyrok NSA z 12 VII 2019 r., I OSK 710/17, Legalis nr 2194129; wyrok NSA z 23 III 2017 r., I OSK 436/16, Legalis nr 1632185.

${ }^{11}$ Legalis nr 1632706.
} 
Przejawy braku zachowania dyscypliny służbowej nie tylko niekorzystnie wpływają na innych funkcjonariuszy, gdyż mogą prowadzić do rozluźnienia dyscypliny służbowej, lecz także istnieje zagrożenie, że mogą stworzyć negatywny obraz całej formacji w oczach opinii publicznej. Pragmatyka służbowa stawia funkcjonariuszom wyższe niż przeciętne wymagania $\mathrm{w}$ zakresie poszanowania przepisów prawa. Są oni zobowiązani nie tylko do spełniania wymogów określonych w art. 44 ustawy o ABW oraz $\mathrm{AW}^{12}$, lecz także do postępowania zgodnie z rotą złożonego ślubowania ${ }^{13}$. Naruszenie obowiązków służbowych, jakim jest niestosowanie się do nakazów i zakazów wynikających $\mathrm{z}$ ustawy o ABW oraz AW, lub też inne zachowania niezgodne $\mathrm{z}$ prawem mogą być uznane za zachowania naruszające ważny interes służby, a tym samym mogą skutkować zwolnieniem funkcjonariusza ze służby.

Nie sposób jednak w ramach jednego opracowania odnieść się do wszystkich wyżej wymienionych obowiązków funkcjonariusza. Dlatego dalsze rozważania zostały skoncentrowane na jednym $\mathrm{z}$ nich, uregulowanym $\mathrm{w}$ art. 81 ust. 1 ustawy o ABW oraz AW. Zgodnie z tym artykułem funkcjonariusz ABW oraz AW nie może być członkiem partii politycznej ani uczestniczyć w działalności tej partii lub na jej rzecz ${ }^{14}$. Prima facie ten zakaz dotyczy wszelkiej aktywności funkcjonariusza, która mogłaby się wiązać $\mathrm{z}$ jego formalną przynależnością do partii politycznej, a także z aktywnością niemającą takiego charakteru, ale bezpośrednio wiążącą się z działalnością (funkcjonowaniem) tego typu partii. Ten problem wydaje się mieć istotne znaczenie, gdyż wytycza granicę dozwolonego zachowania funkcjonariusza. W interesie służby jest natomiast to, aby zakres jego dozwolonej aktywności był precyzyjnie wytyczony. Ważne jest więc wskazanie, jakiego działania funkcjonariusz nie może podejmować, aby nie narazić się na negatywne następstwa, które mogą być konsekwencją nieprzestrzegania zakazu ustanowionego w pragmatyce służbowej. Ten temat nie był dotychczas przedmiotem dogłębnej analizy w doktrynie i nie poświęcono mu szerszego opracowania.

Omawiana problematyka dotyczy samych funkcjonariuszy, ale przede wszystkim ich przełożonych, którzy są zobligowani zarówno do egzekwowania praw i obowiązków funkcjonariuszy wynikających ze stosunku służbowego, jak i do dbałości o utrzymanie dyscypliny służbowej przez swoich podwładnych, a tym samym - do zachowania i utrwalania modelu hierarchicznej struktury organizacyjnej formacji zmilitaryzowanej. Niniejszy artykuł stanowi próbę udzielenia odpowiedzi na pytanie dotyczące granic dozwolonego zachowania funkcjonariusza. W związku z tym konieczne jest wskazanie, jakie zachowanie (działanie lub w szerszym aspekcie - aktywność)

12 Por. z wyrokiem NSA z 16 I 2020 r., I OSK 2748/18, Legalis nr 2287530, oraz z wyrokiem NSA z 16 I 2020 r., I OSK 2949/18, Legalis nr 2282018, w którym sąd wskazał, że pojęcie „ważny interes służby" należy wiązać z przymiotami stanowiącymi wymogi formalne niezbędne do pełnienia służby w Policji.

13 Wyrok NSA z 18 V 2018 r., I OSK 2439/16...

14 Pomimo wielu zmian w ustawie o ABW oraz AW treść art. 81 ust. 1 tej ustawy się nie zmieniła. Por. z art. 81 ust. 1 ustawy o ABW oraz AW w pierwotnym brzmieniu (DzU z 2002 r. nr 74 poz. 676 , ze zm.). 
funkcjonariuszy będzie naruszać dyspozycję normy prawnej zawartej w art. 81 ust. 1 ustawy o ABW oraz AW.

Nawiązanie stosunku służbowego, co już wyżej zaznaczono, immanentnie łączy się z koniecznością powstrzymania się przez funkcjonariusza przed określoną aktywnością związaną z działalnością partii politycznych, manifestowaniem poglądów politycznych, wspieraniem tych partii, działaniem na ich rzecz itp. Stąd też konieczne jest poprzedzenie rozważań stanowiących zasadniczą część tego opracowania omówieniem problematyki dotyczącej konstytucyjnie zagwarantowanej wolności zrzeszania się w partii politycznej. Funkcjonariusz, przyjmując akt mianowania inicjujący stosunek służbowy, zrzeka się części swoich praw i wolności, jakie ma ogół społeczeństwa. Musi zatem mieć świadomość, jaki zakres ma to zrzeczenie. Tylko w ten sposób podjęta przez niego decyzja może być uznana za w pełni świadomą, a tym samym może stanowić podstawę do stwierdzenia, że funkcjonariusz ma zdolność do poddania się szczególnemu reżimowi wynikającemu $\mathrm{z}$ charakteru służby w formacji, w której chce tę służbę pełnić.

\section{Wolność zrzeszania się w partiach politycznych a możliwość ograniczenia tej wolności}

Konstytucja Rzeczpospolitej Polskiej z 2 kwietnia 1997 r. ${ }^{15}$ w art. 11 ust. 1 stanowi, że Rzeczpospolita Polska zapewnia wolność tworzenia i działania partii politycznych ${ }^{16}$. Partie zrzeszają obywateli polskich na zasadach dobrowolności i równości w celu wpływania metodami demokratycznymi na kształtowanie polityki państwa. Jak zaznacza doktryna, w zakresie przynależności do partii politycznych Konstytucja RP rozstrzyga trzy sprawy: przesądza, że członkiem partii może być tylko obywatel polski ${ }^{17}$; wymaga, aby członkostwo w partii było dobrowolne oraz aby było oparte na zasadach równości ${ }^{18}$. To oznacza, że obywatel polski nie może zostać wcielony do żadnej partii politycznej wbrew swojej wiedzy lub woli, ponieważ członkostwo w partii musi być oparte na dobrowolności i równości. Konstytucja RP bowiem zapewnia każdemu wolność zrzeszania się (art. 58 ust. 1 Konstytucji RP) ${ }^{19}$. Jak słusznie zaznacza się w doktrynie,

15 DzU z 1997 r. nr 78 poz. 483, ze zm.

16 Szerzej na temat pojęcia partia polityczna zob. M. Chmaj, M. Żmigrodzki, Status prawny partii politycznych $w$ Polsce, Torun 1995, s. 7 i nast.

17 Przeciwnego zdania jest Marcin Dąbrowski, który twierdzi, że taki pogląd nie znajduje podstaw w treści przepisów ustawy zasadniczej, jest niewystarczająco uzasadniony i budzi wiele poważnych wątpliwości. Zob. tenże, Konstytucyjny aspekt zrzeszania się cudzoziemców w partiach politycznych w Polsce, „Przegląd Sejmowy” 2011, nr 2, s. 114.

18 Konstytucja RP. Tom I. Komentarz do art. 1-86, M. Safjan, L. Bosek (red.), Warszawa 2016, (komentarz do art. 11 Konstytucji RP).

19 Piotr Winczorek zalicza wolność zrzeszania się w partiach politycznych do wolności i praw politycznych. Odnoszą się one do udziału jednostki w życiu politycznym społeczeństwa, a tym samym 
(...) wolność zrzeszania się oznacza swobodę tworzenia przez obywateli różnego rodzaju organizacji, funkcjonujacych dla realizacji wytyczonych przez nich celów ${ }^{20}$. W Konstytucji RP określono jedynie ramy, w jakich ta wolność może być realizowana. Jedną z nich jest wolność zrzeszania się w partii politycznej ${ }^{21}$.

Szczegółowe uregulowania dotyczące partii politycznych zostały zawarte w ustawie zwykłej, tj. Ustawie $z$ dnia 27 czerwca 1997 r. o partiach politycznych ${ }^{22}$ (dalej: ustawa o partiach politycznych). Przepis art. 1 ust. 1 tej ustawy definiuje partię polityczną jako dobrowolną organizację występującą pod określoną nazwą, stawiającą sobie za cel udział w życiu publicznym przez wywieranie metodami demokratycznymi wpływu na kształtowanie polityki państwa lub sprawowanie władzy publicznej ${ }^{23}$. Jest ona zatem formą zrzeszenia, za którego pośrednictwem społeczeństwo wyraża swoją wolę polityczną, a także - pośrednio - wpływa na kierunek i sposób sprawowania władzy publicznej ${ }^{24}$. Partia polityczna może korzystać z praw wynikających $\mathrm{z}$ ustaw dopiero po uzyskaniu wpisu do ewidencji partii politycznych (art. 1 ust. 2 ustawy o partiach politycznych). Ta regulacja wskazuje również, że członkami partii politycznej mogą być obywatele Rzeczpospolitej Polskiej, którzy ukończyli 18 lat (art. 2 ust. 1 ustawy o partiach politycznych).

Sprawy związane $\mathrm{z}$ członkostwem $\mathrm{w}$ partii politycznej zostały zastrzeżone jako materia statutowa każdej tego typu partii. Zgodnie z treścią art. 9 ust. 1 pkt 2 ustawy o partiach politycznych sposób nabywania i utraty członkostwa w partii politycznej określa statut tej partiii ${ }^{25}$. Tym samym statut każdej partii politycznej może w sposób odmienny określać zasady, na jakich osoba może się ubiegać o bycie jej członkiem, a także sposoby pozbawienia tego prawa, tj. wykluczenia z grona osób będących członkami takiej partii. Statut partii nie może jednak naruszyć gwarancji wynikających z postanowień Konstytucji RP. Nie może więc ustanowić reguł, które nie respektowałyby zasady równości i dobrowolności w ubieganiu się o członkostwo w danej partii politycznej, a także możliwości wystąpienia z niej. Autonomia partii politycznej w zakresie określania celu, struktury, zasad działania, a zwłaszcza sposobu nabywania i utraty

do udziału w sprawowaniu władzy publicznej. Zob. tenże, Prawo konstytucyjne Rzeczypospolitej Polskiej, Warszawa 2003, s. 91; także: W. Skrzydło, Polskie prawo konstytucyjne, Lublin 1997, s. 188; Prawo administracyjne, J. Boć (red.), Wrocław 2001, s. 450.

20 Prawo konstytucyjne RP, P. Sarnecki (red.), Warszawa 2011, s. 131.

${ }^{21}$ Szerzej na ten temat zob. J. Oniszczuk, Konstytucja Rzeczypospolitej Polskiej w orzecznictwie Trybunału Konstytucyjnego na początku XXI w., Kraków 2004, s. 664 i nast.

22 Tekst jednolity: DzU z 2018 r. poz. 580.

${ }^{23}$ Jest to podstawowy cel każdej partii politycznej (wyrok NSA z 18 XII 2014 r., I OSK 611/14, Legalis nr 1330014).

${ }^{24}$ Prawo konstytucyjne RP..., s. 132. W tym samym duchu wypowiada się Piotr Tuleja. Zob. Prawo konstytucyjne, P. Tuleja (red.) Warszawa 1995, s. 96.

25 Statut partii politycznej jest uchwalany przez zgromadzenie ogólne członków partii lub zgromadzenie przedstawicieli członków partii wybranych w sposób demokratyczny (art. 9 ust. 2 ustawy o partiach politycznych). 
członkostwa w niej, nie ma zatem charakteru bezwzględnego. Te granice wytycza zarówno Konstytucja RP, jak i ustawa o partiach politycznych.

Prawo do tworzenia partii politycznych i uczestnictwa w ich działalności przysługuje, co do zasady, każdemu obywatelowi RP na tych samych zasadach. Zakaz przynależności do partii politycznych musi wynikać z przepisu szczególnego o randze ustawy (art. 2 ust. 2 ustawy o partiach politycznych).

Takie ograniczenie zostało wprowadzone w art. 81 ust. 1 ustawy o ABW oraz AW. Identyczne rozwiązanie zostało przewidziane również $\mathrm{w}$ innych formacjach zmilitaryzowanych ${ }^{26}$, o czym stanowią: art. 73 ust. 1 Ustawy z dnia 9 czerwca 2006 r. o Centralnym Biurze Antykorupcyjnym ${ }^{27}$, art. 40 ust. 1 Ustawy z dnia 9 czerwca 2006 r. o służbie funkcjonariuszy Służby Kontrwywiadu Wojskowego oraz Służby Wywiadu Wojskowe$g^{28}$, art. 139 ust. 1 Ustawy z dnia 8 grudnia 2017 r. o Służbie Ochrony Państwa ${ }^{29}$ oraz art. 47 ust. 1 Ustawy z dnia z dnia 26 stycznia 2018 r. o Straży Marszałkowskiejo. Należy również dodać, że taka sama treść jak w art. 81 ust. 1 ustawy o ABW oraz AW została zawarta także w art. 50 ust. 1 nieobowiązującej już Ustawy z dnia 6 kwietnia 1990 r. o Urzędzie Ochrony Państwa ${ }^{31}$. Ta regulacja poprzedzała ustawę o ABW oraz $\mathrm{AW}^{32}$.

Podobnie w art. 63 ust. 1 Ustawy $z$ dnia 6 kwietnia 1990 r. o Policji ${ }^{33}$ zawarto zapis, że policjant nie może być członkiem partii politycznej. Taka sama redakcja przepisu została zamieszczona w art. 163 Ustawy z dnia 9 kwietnia 2010 r. o Służbie Więziennej ${ }^{34}$, w art. 68 ust. 1 Ustawy z dnia 12 października 1990 r. o Straży Granicznej ${ }^{35}$, w art. 202 ust. 1 pkt 1 Ustawy $z$ dnia 16 listopada 2016 r. o Krajowej Administracji Skarbowej ${ }^{36}$ oraz w art. 57c ust. 1 Ustawy z dnia 24 sierpnia 1991 r. o Państwowej Straży Pożarnej37. Zgodnie z art. 106 ust. 1 pkt 1-3 Ustawy z dnia 11 września 2003 r. o stużbie wojskowej żołnierzy zawodowych ${ }^{38}$ żołnierzowi zawodowemu w czasie pełnienia zawodowej słuźby wojskowej nie wolno: być członkiem partii politycznej, stowarzyszenia, organizacji

${ }^{26}$ Jak zaznacza M. Wieczorek, zakaz zrzeszania się w partiach politycznych jest zawarty we wszystkich pragmatykach służbowych (służb zmilitaryzowanych - przyp. aut.). Tenże, Charakter prawny stosunków służbowych..., s. 318.

27 Tekst jednolity: DzU z 2019 r. poz. 1921, ze zm.

28 Tekst jednolity: DzU z 2020 r. poz. 1221, ze zm.

29 Tekst jednolity: DzU z 2020 r. poz. 384, ze zm.

30 Tekst jednolity: DzU z 2019 r. poz. 1940, ze zm.

31 Tekst jednolity: DzU z 1999 r. nr 51 poz. 526.

32 Na podstawie art. 234 ustawy o ABW oraz AW; ustawa o Urzędzie Ochrony Państwa utraciła moc.

33 Tekst jednolity: DzU z 2020 r. poz. 360, ze zm.

34 Tekst jednolity: DzU z 2020 r. poz. 848, ze zm. Porównaj także z art. 64 ust. 1 nieobowiązującej Ustawy z dnia 26 kwietnia 1996 r. o Stużbie Więziennej (t.j.: DzU z 2002 r. nr 207 poz. 1761, ze zm.).

35 Tekst jednolity: DzU z 2020 r. poz. 305, ze zm.

36 Tekst jednolity: DzU z 2021 r. poz. 422. Porównaj także z art. 125 pkt 1 nieobowiązującej Ustawy z dnia 27 sierpnia 2009 r. o Stużbie Celnej (t.j.: DzU z 2016 r. poz. 1799, ze zm.).

37 Tekst jednolity: DzU z 2020 r. poz. 1123, ze zm.

38 Tekst jednolity: DzU z 2020 r. poz. 860, ze zm. 
lub ruchu obywatelskiego stawiających sobie cele polityczne, brać udziału w zgromadzeniach o charakterze politycznym, a także prowadzić działalności politycznej ${ }^{39}$.

Jednocześnie trzeba zaznaczyć, że ograniczenia w zakresie członkostwa funkcjonariuszy poszczególnych służb w partiach politycznych, wprowadzone w wyżej wymienionych aktach, nie naruszają istoty prawa określonego w ustawie zasadniczej i w ustawie o partiach politycznych. Jak bowiem zaznaczył Trybunał Konstytucyjny (dalej: TK) w wyroku z 10 kwietnia 2002 r. (sygn. akt K 26/00) ) $^{40}$ art. 2 ust. 2 ustawy o partiach politycznych oraz przepisy pozostałych pragmatyk służbowych wprowadzających zakaz członkostwa w partiach politycznych (w tym szczególnie żołnierzy zawodowych, policjantów, funkcjonariuszy Urzędu Ochrony Państwa, Straży Granicznej, Służby Więziennej, Służby Celnej) są zgodne m.in. z art. 11 ust. 1 Konstytucji RP.

Zdaniem Trybunału Konstytucyjnego:

(...) zakaz członkostwa w partiach politycznych osób sprawujących określone funkcje $w$ aparacie państwowym nie wynika $z$ dążenia do ograniczenia praw obywatelskich tych kategorii osób, ale zapobiega konfliktom interesów i ról wynikających z wykonywania służby publicznej i prowadzenia działalności na rzecz określonej partii. Istotą członkostwa w partii politycznej wyraźnie formułowaną w statutach większości partii politycznych, jest obowiązek stosowania się do uchwał statutowych organów partyjnych i czynnego uczestnictwa w kształtowaniu i realizacji programu partii. Przyjęcie tego rodzaju zobowiązań nie jest obojętne z punktu widzenia obowiązków ciążących na funkcjonariuszach służb publicznych oraz pozostawaniu tych służb pod politycznym kierownictwem rządu tworzonego w oparciu o aktualną większość parlamentarną. Z punktu widzenia etyki funkcjonariusza służb publicznych niepożądana jest sytuacja, w której osoba korzystająca z prawa, przysługującego mu jako obywatelowi, narusza obowiązki wynikające $z$ tytułu pełnienia służby publicznej. «Demokratyczne państwo prawne nie powinno być państwem partii. Przy wszystkich sprzężeniach między partiami a państwem potrzebny jest pewien dystans. Poddanie partii reżimowi prawa wywołuje ten skutek, że organy stosowania prawa, jak sądy, prokuratura czy policja, a w jakimś stopniu również i organy orzecznictwa administracyjnego, powinny być wolne od oddziaływania partii politycznych ${ }^{41}$.

W ocenie TK ustawodawca może ustanowić hierarchię określonych wartości i dać prymat jednym, tj. bezpieczeństwu państwowemu lub porządkowi publicznemu, przed innymi, szczególnie przed wartością, jaką jest wolność zrzeszania się, jeśli w określonych okolicznościach zachodzi kolizja pomiędzy tymi wartościami.

39 Porównaj z art. 68 ust. 1 pkt 1-4 nieobowiązującej Ustawy z dnia 30 czerwca 1970 r. o stużbie wojskowej żolnierzy zawodowych (t.j.: DzU z 1997 r. nr 10 poz. 55, ze zm.).

40 Legalis nr 53826, OTK Seria A 2002, nr 2, poz. 18; także: DzU z 2002 nr 56 poz. 517.

${ }^{41}$ Przywołany w cytowanym orzeczeniu. Cyt. za: W. Sokolewicz, Partie polityczne $w$ polskim prawie konstytucyjnym: wczoraj, dziś, jutro, „Studia Prawnicze” 1991, z. 4, bez paginacji. 
W dalszych rozważaniach TK odniósł się stricte do zakazu ustanowionego dla funkcjonariuszy Policji. Wskazał, że:

(...) zakaz członkostwa w partiach politycznych funkcjonariuszy Policji znajduje uzasadnienie zarówno w zadaniach tej służby i wynikających z nich uprawnień funkcjonariuszy, jak i z systemu organizacji Policji, opartego na zasadach dyscypliny i pełnej podległości podwładnych przełożonym. Działania w sferze zapewnienia bezpieczeństwa i porządku publicznego mogą być podejmowane i prowadzone z motywów politycznych i w szerokim zakresie wykorzystywane dla celów o takim charakterze. W ocenie TK, zwłaszcza tam, gdzie zakres powierzonych kompetencji jest na tyle szeroki, że wkracza w sferę praw i wolności innych osób, zrozumiałe jest wprowadzenie takich uregulowań, które tworzą bardziej rygorystyczne gwarancje bezstronności tych organów. Zgodnie z art. 1 ustawy o Policji (Dz.U. z 2002 r. Nr 7, poz. 58) do jej podstawowych zadań należy ochrona życia i zdrowia ludzi oraz mienia, ochrona bezpieczeństwa i porządku publicznego, wykrywanie przestępstw i wykroczeń oraz ściganie ich sprawców, kontrola przestrzegania przepisów porządkowych i administracyjnych związanych z działalnością publiczną. W granicach swych kompetencji Policja wykonuje czynności operacyjno-rozpoznawcze, dochodzeniowo-śledcze i administracyjno-porządkowe. Policja może, w zakresie koniecznym do wykonywania jej ustawowych zadań, korzystać z informacji o osobie, uzyskanych przez UOP i Straż Graniczną (art. 14 ustawy o Policji). Funkcjonariusze Policji dysponują szeregiem uprawnień, łącznie ze stosowaniem środków przymusu bezpośredniego (art. 15 i art. 16 ustawy o Policji), które w sposób bardzo istotny wkraczają w sferę praw i wolności jednostki. W związku z tym uzasadnione jest istnienie ograniczeń praw funkcjonariuszy, gwarantujących ich neutralność polityczną ${ }^{42}$.

Jednocześnie TK zaznaczył, że zaprezentowane stanowisko należy odnieść również do funkcjonariuszy innych służb (formacji zmilitaryzowanych), które pełnią funkcje i wykonują zadania o charakterze zbliżonym do funkcji i zadań Policji. Mają one bowiem - w szerszym lub węższym zakresie - uprawnienia do stosowania instrumentów, które wkraczają bezpośrednio w sferę podstawowych praw i wolności obywatelskich, w tym do stosowania środków przymusu bezpośredniego. Zatem argumentacja odnosząca się wprost do zakazu członkostwa funkcjonariuszy Policji w partiach

42 Por. także: „Biorąc pod uwagę art. 10, 11 oraz 14 Konwencji o Ochronie Praw Człowieka i Podstawowych Wolności z dnia 4 listopada 1950 r. (Dz.U. z 1993 r., Nr 61, poz. 284) Trybunał stwierdza, że państwo może uznać za konieczne konstytucyjne zagwarantowanie politycznej neutralności sił policyjnych i wprowadzenie regulacji dotyczących ograniczeń w zakresie stowarzyszeń w dziedzinie polityki wobec funkcjonariuszy Policji. Funkcjonariusze są bowiem uprawnieni do stosowania przymusu przy regulowaniu zachowania obywateli, w niektórych krajach są uzbrojeni, a siły policyjne pozostają na służbie państwa. Społeczeństwo może więc oczekiwać, iż w swoich relacjach z Policją będzie miało do czynienia z neutralnymi politycznie funkcjonariuszami” (wyrok Europejskiego Trybunału Praw Człowieka z 20 V 1999 r., sygn. 25390/94, Legalis nr 102542). 
politycznych musi być odniesiona per analogiam do funkcjonariuszy służb zobowiązanych do wykonywania zadań podobnych do zadań Policji i dysponujących podobnymi uprawnieniami oraz mających strukturę hierarchiczną opartą na podległości służbowej w stosunkach pomiędzy przełożonym a podwładnym i szczególnej dyscyplinie.

Stanowisko zaprezentowane przez TK pozostaje aktualne również w odniesieniu do zakazu wprowadzonego w ustawie o ABW oraz AW. Nie może budzić wątpliwości to, że szczególny charakter służby publicznej pełnionej przez funkcjonariuszy ABW i AW, zwłaszcza w świetle zadań przewidzianych dla tych formacji (wymienionych w art. 5 i art. 6 ustawy o ABW oraz AW), wymaga zagwarantowania ich politycznej neutralności. Ten zakaz ma służyć wyeliminowaniu lub znacznemu ograniczeniu jakichkolwiek wątpliwości, że działania podejmowane przez funkcjonariuszy, a tym samym przez samą formację $e^{43}$, zwłaszcza w stosunku do obywateli, są inspirowane motywami lub pobudkami o charakterze politycznym ${ }^{44}$. Wymienione formacje, jak już wspomniano, mają bowiem szerokie uprawnienia do ingerencji w sferę praw i wolności ludzi. Społeczeństwo musi więc mieć przekonanie, że zadania realizowane przez ABW lub AW służą wypełnieniu misji tych organizacji. Tym samym wymienione formacje muszą się cieszyć pełnym zaufaniem społecznym. Ma to szczególne znaczenie w kontekście jawności ich działań. Ludzie nie mają (i w bardzo wielu przypadkach nie będą mieli) wiedzy o zakresie i celu poszczególnych zadań realizowanych przez te formacje. Muszą wobec tego mieć przekonanie, że determinantą do ich podjęcia jest wyłącznie zamiar wykonania przez ABW lub AW zadań określonych w ustawie kompetencyjnej oraz że te zadania nie są uzasadnione polityczną wolą konkretnej grupy reprezentującej określony pogląd polityczny lub wolą partii politycznej.I mimo że nie wynika to wprost ze stanowiska TK, gdyż oceniał on zgodność

${ }_{43}$ Jak słusznie zaznacza TK (wyrok TK z 15 IX 1999 r., K 11/99, OTK 1999 r., nr 6, poz. 116, Legalis $\mathrm{nr} 45366)$ : „(...) pojęcie funkcjonariusza pozostaje zawsze $\mathrm{w}$ nierozerwalnym związku z instytucją, bądź strukturą[,] w ramach której i na rzecz której funkcjonariusz działa. Z jednostki organizacyjnej czy też organu, z którym jest związany, funkcjonariusz czerpie upoważnienie i umocowanie do podejmowanych przez siebie działań. Można w związku z tym mówić o swoistej identyfikacji tychże działań z celami organizacji[,] na rzecz której działa. Poszczególne działania funkcjonariusza pozostające $\mathrm{w}$ związku $\mathrm{z}$ wykonywaną przez niego funkcją wywierają skutki dla jednostki organizacyjnej[,] z którą jest związany. Działalność samej jednostki organizacyjnej jest w praktyce uzewnętrzniana przez jej organy i funkcjonariuszy. Funkcjonariusz zatem zapewnia organizacji (organowi) możliwość działania poprzez realizację właściwych dla niej zadań merytorycznych. Status funkcjonariusza jest ściśle związany z realizowaniem merytorycznych zadań jednostki organizacyjnej (organu), a przez to podstawowych ich celów".

${ }^{44}$ M. Wieczorek, Charakter prawny stosunków stużbowych..., s. 31; także: B. Opaliński, M. Rogalski, P. Szustakiewicz, Ustawa o Straży Granicznej. Komentarz, Warszawa 2019, Legalis (komentarz do art. 68 ustawy o Straży Granicznej). Analogiczne uzasadnienie prezentuje Adam Zdunek w odniesieniu do funkcjonariuszy Krajowej Administracji Skarbowej. Twierdzi on, że „(...) te zakazy uzasadnione są specyfiką pełnienia służby w Służbie Celno-Skarbowej i koniecznością zagwarantowania niezależności funkcjonariusza”. Zob. Ustawa o Krajowej Administracji Skarbowej. Komentarz, L. Bielecki, A. Gorgol (red.), Warszawa 2018, Legalis (komentarz do art. 202 ustawy o Krajowej Administracji Skarbowej); także: „Regulacja ta ma na celu zapewnienie gwarancji bezstronnego wykonywania przez policjantów powierzonych im zadań służbowych”. Zob. Ł. Czebotar i in., Ustawa o Policji. Komentarz, Warszawa 2015, s. 482. 
przepisów pragmatyk służbowych dotyczących zakazu przynależności funkcjonariuszy służb zmilitaryzowanych (zwłaszcza funkcjonariuszy Policji) do partii politycznych z Konstytucją RP, to niewątpliwie z treści cytowanych fragmentów orzeczenia można wywieść uzasadnienie wprowadzenia tego rodzaju ograniczeń w stosunku do funkcjonariuszy publicznych. Funkcjonariusze publiczni bowiem mają przede wszystkim realizować zadania wyznaczone formacji, w której pełnią służbę. Informacja o formalnej lub nieformalnej przynależności funkcjonariusza danej służby do określonej partii politycznej może wpływać na zdolność do realizacji przez niego zadań, a tym samym - na efektywność realizacji zadań służby. Ograniczenia wprowadzone dla funkcjonariuszy są zatem, jak słusznie zaznacza TK, gwarancją neutralności politycznej i bezstronności tych organów.

\section{Istota zakazu wynikającego $\mathrm{z}$ art. 81 ust. 1 ustawy o ABW oraz AW}

Jak już wcześniej wspomniano, z treści art. 81 ust. 1 ustawy o ABW oraz AW wyni$\mathrm{ka}$, że funkcjonariusz ABW lub AW nie może być członkiem partii politycznej ani uczestniczyć w działalności tej partii lub na jej rzecz. To oznacza, że tym przepisem ustanowiono dwa odrębne zakazy. Pierwszy z nich to zakaz członkostwa w partii politycznej ${ }^{45}$. Odnosi się on do partii politycznych legalnie działających w polskim porządku prawnym. Nie można bowiem odnieść go do nieformalnych organizacji, które nie spełniają kryteriów wskazanych przez przepisy ustawy o partiach politycznych ${ }^{46}$, a także do organizacji, których działalność jest zakazana przez przepisy prawa. Zakaz ten należy stricte odnieść do partii politycznej spełniającej kryteria, o których mowa w art. 1 ust. 1 ustawy o partiach politycznych. Przy założeniu, że ustawodawca jest racjonalny, jeśli posłużyłby się pojęciem partia polityczna w innym znaczeniu niż $\mathrm{w}$ ustawie o partiach politycznych, wskazałby to expressis verbis $\mathrm{w}$ konkretnym przepisie pragmatyki służbowej. Skoro nie zawarł takiego zastrzeżenia, to konieczne jest ustalenie zakresu znaczeniowego tego pojęcia na podstawie aktu prawnego, który taką definicję zawiera, tj. ustawy o partiach politycznych. Przeciwne stanowisko prowadziłoby do wniosku, że system prawa nie jest spójny.

Należy podkreślić, że zakaz członkostwa w partii politycznej ma charakter bezwzględny ${ }^{47}$. Tym samym od chwili zainicjowania z osobą fizyczną stosunku służbowego

${ }^{45}$ Jest to formalny zakaz bycia członkiem partii politycznej. Zob. B. Opaliński, M. Rogalski, P. Szustakiewicz, Ustawa o Agencji Bezpieczeństwa Wewnętrznego... (komentarz do art. 81 ustawy o ABW oraz AW).

${ }^{46}$ Nie musi to jednak być partia wpisana do ewidencji partii politycznych, wpis powoduje bowiem, że nabywa ona osobowość prawną i może korzystać z praw wynikających z ustaw. Brak wpisu nie pozbawia jej przymiotu partii politycznej. Jest nią już na etapie jej tworzenia, jeśli spełnia kryteria wskazane w ustawie o partiach politycznych. Por. Prawo administracyjne, E. Ura (red.), Rzeszów 1997, s. 554.

47 B. Opaliński, M. Rogalski, P. Szustakiewicz, Ustawa o Agencji Bezpieczeństwa Wewnętrznego... (komentarz do art. 81 ustawy o ABW oraz AW); zob. także: B. Opaliński, P. Szustakiewicz, Agencja Bezpieczeństwa Wewnętrznego... 
w ABW albo w AW aż do jego zakończenia, tj. do jego rozwiązania, funkcjonariusz nie może być członkiem takiej partii. Sprawy związane z członkostwem zostały zastrzeżone dla statutów poszczególnych partii politycznych. W tych aktach wskazuje się zarówno warunki, na jakich osoba dobrowolnie składająca oświadczenie woli o wstąpieniu do partii politycznej może się stać jej członkiem, jak i wyznacza moment, kiedy dana osoba staje się członkiem tej partii, a także, kiedy przestaje nim być - po złożeniu oświadczenia o wystąpieniu z partii. Istotne z punktu widzenia omawianej problematyki jest zatem to, że w momencie nawiązania przez osobę fizyczną stosunku służbowego nie może ona już być członkiem żadnej partii politycznej. Jeśli wystąpienie z danej partii politycznej wymaga przeprowadzenia (zwłaszcza przez organy statutowe tej partii) określonej sekwencji czynności, których wykonanie skutkuje utratą tego członkostwa, to zasadne wydaje się, że złożenie wyłącznie samego oświadczenia woli o wystąpieniu członka z tej partii (np. wniosku o wykreślenie go z listy członków) nie spełniałoby warunku, o którym mowa w art. 81 ust. 1 ustawy o ABW oraz AW. W chwili zainicjowania stosunku służbowego osoba fizyczna musi zostać definitywnie pozbawiona statusu członka partii politycznej. Zatem, jeśli statut partii politycznej przewiduje określoną procedurę z tym związaną, to musi ona zostać dopełniona. Przepis art. 81 ust. 1 ustawy o ABW oraz AW odnosi się bowiem do formalnego węzła, jaki spaja organizację (partię polityczną) z osobą fizyczną (jej członkiem). Nie obejmuje on psychicznego nastawienia danej osoby co do tego, czy ona chce czy nie chce być członkiem określonej partii politycznej. Nie ma również znaczenia, jakie czynności czy działania podejmowała osoba fizyczna lub też jaką aktywnością się wykazała w celu pozbawienia siebie statusu członka partii politycznej. Istotne jest wyłącznie to, czy w okresie trwania stosunku służbowego (od chwili jego zainicjowania do momentu jego utraty) osoba fizyczna (funkcjonariusz) formalnie ma status członka partii politycznej. Odmienna interpretacja nie wytrzymuje krytyki, gdyż osoba fizyczna, składając oświadczenie o wystąpieniu z partii politycznej (zwłaszcza jeśli takie oświadczenie złożyłaby za pośrednictwem poczty lub innego środka komunikacji na odległość), nie byłaby zobowiązana do zweryfikowania, czy rzeczywiście to oświadczenie dotarło do adresata, tj. partii politycznej, a jeśli dotarło, to czy wywołało skutek w postaci pozbawienia jej członkostwa w tej partii. Mogłoby to powodować, że taka osoba nie utraciłaby tego statusu w okresie trwania stosunku służbowego. Należy podkreślić, że ten obowiązek dotyczy wyłącznie formalnego węzła łączącego partię polityczną z jej członkiem. Pozbawienie członkostwa musi polegać na definitywnym zerwaniu tej więzi. Nie może zatem nim być ani zawieszenie członkostwa, ani zawieszenie wykonywania praw członkowskich w partii politycznej.

Z treści art. 63 ust. 2 ustawy o Policji wynika, że z chwilą przyjęcia policjanta do służby ustaje jego dotychczasowe członkostwo w partii politycznej ${ }^{48}$. Ustawa o ABW

48 Tak samo w: art. 139 ust. 2 ustawy o Służbie Ochrony Państwa, art. 163 ust. 2 ustawy o Służbie Więziennej, art. 68 ust. 2 ustawy o Straży Granicznej, art. 57c ust. 2 ustawy o Państwowej Straży Pożarnej, art. 106 ust. 3 ustawy o służbie wojskowej żołnierzy zawodowych, a także w art. 50 ust. 2 nieobowiązującej ustawy o Urzędzie Ochrony Państwa. 
oraz AW nie zawiera podobnie brzmiącego przepisu. Jeśli kandydat przed przyjęciem go do służby w ABW albo AW był członkiem partii politycznej, to musi z własnej inicjatywy podjąć aktywność zmierzającą do definitywnego pozbawienia go tego statusu. Samo nawiązanie stosunku służbowego nie powoduje bowiem ipso iure takiego skutku.

Pragmatyka służbowa, chociaż posługuje się pojęciem c zło n ko s t wo, to nie wyjaśnia, czym ono w istocie jest. Również w ustawie o partiach politycznych nie zawarto definicji legalnej tego pojęcia. Ze względu na jej brak należałoby się odnieść do znaczenia, jakie ono ma w języku potocznym. „Członkostwo” to przynależność do jakiejś

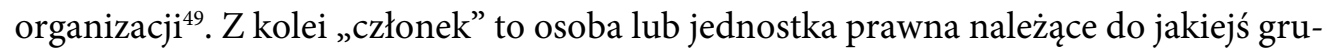
py, organizacji ${ }^{50}$. W uzupełnieniu wypada jedynie wskazać, że przez „przynależność” należałoby rozumieć sformalizowaną więź prawną skutkującą tym, że osoba fizyczna staje się elementem składowym danej organizacji - tworzy jej szeregi. Trzeba również zaznaczyć, że członkostwo w partii politycznej, w kontekście dobrowolnej przynależności do tego rodzaju organizacji, jest - co do zasady - immanentnie związane z psychicznym nastawieniem obywatela RP, który utożsamiając się z określonymi ideami, poglądami, programem politycznym, chce współuczestniczyć w realizacji celu danej partii. Niemniej, jak zostało to już wcześniej zaznaczone w odniesieniu do tematu poruszanego $\mathrm{w}$ artykule, członkostwo w partii politycznej należy utożsamiać wyłącznie z wyżej wymienionym formalnym węzłem prawnym. Tym samym ustalenie rzeczywistego członkostwa funkcjonariusza w partii politycznej jest wystarczające do stwierdzenia, że został naruszony zakaz wynikający z pragmatyki służbowej. Nieistotne są natomiast przyczyny takiego stanu rzeczy, a zwłaszcza brak psychicznej łączności pomiędzy osobą fizyczną a organizacją.

Drugim zakazem wynikającym z art. 81 ust. 1 ustawy o ABW oraz AW jest zakaz uczestniczenia przez funkcjonariusza w działalności partii politycznej lub na jej rzecz $^{51}$. Ten zakaz również ma charakter bezwzględny ${ }^{52}$. W tym przypadku chodzi o takie uczestnictwo w działalności partii politycznej lub na jej rzecz, które nie jest (nie musi być) połączone z członkostwem w tej partii. Samo członkostwo jest już objęte odrębnym

49 https://sjp.pwn.pl/slowniki/cz\%C5\%82onkostwo.html [dostęp: 8 VII 2020].

50 https://sjp.pwn.pl/szukaj/cz\%C5\%82onek.html [dostęp: 8 VII 2020].

${ }^{51}$ Jest to zakaz materialny prowadzenia działalności politycznej. Zob. B. Opaliński, M. Rogalski, P. Szustakiewicz, Ustawa o Agencji Bezpieczeństwa Wewnętrznego... (komentarz do art. 81 ustawy o ABW oraz AW) oraz B. Opaliński, P. Szustakiewicz, Agencja Bezpieczeństwa Wewnętrznego... Ten zakaz obejmuje każdą działalność na rzecz partii politycznej, np. przez uczestnictwo w jej manifestacjach lub pracy jej młodzieżówki. Zob. M. Rogalski, P. Szustakiewicz, P. Złamańczuk, Ustawa o Stużbie Ochrony Państwa. Komentarz, Warszawa 2019, Legalis (komentarz do art. 139 ustawy o Służbie Ochrony Państwa). W. Kotowski wskazuje ponadto (w odniesieniu do policjantów), że ten zakaz obejmuje: uczestnictwo w redagowaniu pisma o charakterze politycznym, autorstwo tekstów do takich czasopism oraz członkostwo w kolegium redakcyjnym takich czasopism. Zob. W. Kotowski, Ustawa o Policji. Komentarz, Warszawa 2008, s. 468.

52 B. Opaliński, M. Rogalski, P. Szustakiewicz, Ustawa o Agencji Bezpieczeństwa Wewnętrznego... (komentarz do art. 81 ustawy o ABW oraz AW); także: B. Opaliński, P. Szustakiewicz, Agencja Bezpieczeństwa Wewnętrznego... 
zakazem i nie musi być połączone z żadną działalnością funkcjonariusza na rzecz tej partii lub uczestnictwem w jej funkcjonowaniu. Naruszenie pierwszego zakazu następuje w momencie, gdy pomiędzy czynnym funkcjonariuszem a partią polityczną istnieje więź prawna, z której wynika, że przynależy on do tej organizacji jako jej członek. Nie musi przy tym wykazywać się żadną aktywnością ani w funkcjonowaniu tej partii, ani też nie musi działać na jej rzecz. Wystarczające jest ustalenie, że będąc funkcjonariuszem, jest również jej członkiem.

Uczestnictwo w działalności partii politycznej lub działanie na jej rzecz może natomiast nie być połączone $\mathrm{z}$ formalnym członkostwem $\mathrm{w}$ tej partii. Może polegać na pełnieniu jakiejś funkcji w określonych władzach lub ciałach statutowych tej partii, zajmowaniu w niej określonego stanowiska, ale również na nieformalnej przynależności do niej lub odgrywaniu określonej roli w jej strukturach. Nie ma również znaczenia, czy takie uczestnictwo ma charakter odpłatny. Chodzi zatem o każdego rodzaju aktywność związaną z działalnością partii politycznej, w tym szczególnie z uczestniczeniem $\mathrm{w}$ procesie jej tworzenia, $\mathrm{w}$ jej funkcjonowaniu, zmianach lub likwidacji, czyli o ustalenie, że działania podejmowane przez funkcjonariusza są nakierowane na to, aby brać udział w działalności danej partii.

Nie oznacza to jednak, że zakaz, o którym mowa, głęboko ingeruje w sferę prywatną osoby fizycznej, a tym samym, że zobowiązuje ją do wyzbycia się poglądów politycznych z chwilą nawiązania stosunku służbowego. Zarówno ABW i AW, jak i inne formacje zmilitaryzowane nie są bowiem organizacjami totalitarnymi. Chodzi natomiast o stworzenie pewnych granic, które uniemożliwią identyfikowanie poszczególnych funkcjonariuszy tych służb z określoną opcją polityczną. Istotą jest intensywność wyrażania przez funkcjonariuszy własnych opinii czy manifestowania swoich poglądów politycznych. Funkcjonariusz nie może przekroczyć pewnego poziomu w manifestowaniu swoich poglądów politycznych, który umożliwiłby łączenie go z konkretną partią polityczną, a w szerszym aspekcie - całej formacji z taką partią. Stąd też istnieje konieczność rezygnacji przez funkcjonariusza $\mathrm{z}$ określonych praw i wolności, jakie ma reszta społeczeństwa, bądź ograniczenia możliwości ich realizacji. Funkcjonariusz może mieć własne przekonania i poglądy o charakterze politycznym, może również korzystać z czynnego prawa wyborczego i głosować w wyborach na kandydata dowolnej partii politycznej, wyrażać zdanie w sprawach politycznych bądź wymieniać poglądy w tym zakresie, $\mathrm{z}$ tym jednak zastrzeżeniem, że nie może tego manifestować publicznie. Może również badać naukowo tę sferę i publikować wyniki przeprowadzonych badań w periodykach o charakterze naukowym, oczywiście z zachowaniem innych wymogów określonych w pragmatyce służbowej (art. 80 ustawy o ABW oraz AW). Zakaz ustanowiony w art. 81 ust. 1 ustawy ma bowiem swoje granice. Funkcjonariusz nie może być ani członkiem partii politycznej, ani uczestniczyć w działalności tej partii lub na jej rzecz. Wobec tego nie może podejmować żadnej aktywności, która skutkowałaby tym, że w społeczeństwie jako funkcjonariusz byłby identyfikowany $z$ określoną partią lub opcją polityczną. Byłoby to, jak zaznacza Mariusz Wieczorek, niezgodne z rotą złożonego ślubowania. Funkcjonariusz, pełniąc służbę, nie 
może kierować się swoimi przekonaniami czy sympatiami politycznymi, ale dobrem wspólnym ${ }^{53}$. Niedopuszczalne wobec tego by było, aby manifestował swoją sympatię dla określonej partii lub opcji politycznej lub też w jakikolwiek sposób agitował na jej rzecz $^{54}$. Nic natomiast nie stoi na przeszkodzie w prowadzeniu przez funkcjonariusza dyskusji na tematy polityczne w gronie rodzinnym. Bezwzględnie niedopuszczalna byłaby tego rodzaju aktywność funkcjonariusza podejmowana przez niego podczas wykonywania czynności służbowych lub w związku z ich wykonywaniem. Mogłoby to świadczyć przede wszystkim o chęci przysporzenia zwolenników danej partii politycznej. To z kolei uzasadniałoby twierdzenie o wykonywaniu przez niego działań na rzecz określonej partii.

Należy również dodać, że zakaz uczestniczenia funkcjonariusza ABW albo AW w działalności partii politycznej lub na jej rzecz nie ma tak wyraźnie zarysowanych granic, jak w przypadku zakazu członkostwa w tego typu partii. Zakaz członkostwa wymaga bowiem wyłącznie ustalenia istnienia relacji mającej charakter sformalizowany, tj. węzła prawnego, który uprawnia do stwierdzenia, że dana osoba jest członkiem określonej partii politycznej. Nie oznacza to jednak, że zakaz uczestnictwa funkcjonariusza ABW albo AW w działalności partii politycznej lub na jej rzecz w ogóle nie ma takich granic, ale w przeciwieństwie do granic zakazu odnoszącego się do członkostwa w partii politycznej zakaz uczestnictwa ma charakter ocenny. Właściwa kwalifikacja jako naruszająca obowiązek powstrzymania się przez funkcjonariusza od uczestnictwa w działalności partii politycznej lub działania na jej rzecz jest wobec tego zależna od studium konkretnego przypadku. Trudno by było stworzyć wyczerpujący katalog sytuacji, które mieściłyby się w granicach tego zakazu. W praktyce byłoby to znacznie utrudnione lub wręcz niemożliwe. Nie może jednak budzić wątpliwości to, że taka ocena nie może mieć charakteru nieograniczonego - arbitralnego. Musi ona wskazywać na to, że określona, świadoma aktywność funkcjonariusza może być obiektywnie łączona $\mathrm{z}$ funkcjonowaniem partii politycznej lub jej działalnością.

\section{Podsumowanie}

Trudno się odnieść do wszystkich aspektów omawianego zagadnienia w ramach jednego opracowania. Liczba stanów faktycznych, jakie można by było wyodrębnić, jest bowiem niezliczona. W artykule skoncentrowano się wyłącznie na wskazaniu określonych obszarów tej tematyki, które pozwolą ją przybliżyć.

Jak wykazano, zakaz ustanowiony w art. 81 ust. 1 ustawy o ABW oraz AW, podobnie jak zakazy zawarte $\mathrm{w}$ innych pragmatykach służbowych funkcjonariuszy służb

53 M. Wieczorek, Charakter prawny stosunków służbowych..., s. 319.

54 Wyrok Wojewódzkiego Sądu Administracyjnego w Lublinie z 11 II 2016 r., III SA/Lu 1108/15, Legalis nr 1434512 (dotyczy policjanta); B. Opaliński, M. Rogalski, P. Szustakiewicz, Ustawa o Agencji Bezpieczeństwa Wewnętrznego... (komentarz do art. 81 ustawy o ABW oraz AW). 
zmilitaryzowanych, ma swoje uzasadnienie w celach i zadaniach tych formacji. Tylko polityczna neutralnośćs5 członków formacji, o których mowa, pozwala na zagwarantowanie właściwej realizacji tych zadań i osiągnięcie celów. Instrumenty prawne, w jakie funkcjonariusze tych służb zostali wyposażeni, umożliwiają głęboką ingerencję w sferę praw i wolności innych osób. Muszą one zatem mieć przekonanie, że te instrumenty nie są i nie będą wykorzystywane w celach politycznych, a formacje są wolne od nacisków zewnętrznych.

Z treści art. 81 ust. 1 ustawy o ABW oraz AW wynikają dwa odrębne obowiązki (zakazy) ustanowione dla czynnego funkcjonariusza. Naruszenie pierwszego z nich następuje już w momencie ustalenia istnienia formalnego węzła, jakim jest członkostwo funkcjonariusza w partii politycznej, chociażby nie było ono połączone z żadną aktywnością z jego strony. Drugi zakaz natomiast jest związany z obowiązkiem powstrzymania się przez funkcjonariusza od podejmowania jakiejkolwiek aktywności, która wskazywałaby na istnienie jakichkolwiek relacji między tą aktywnością a funkcjonowaniem partii politycznej. Uczestnictwo w działalności partii politycznej lub na jej rzecz może objawiać się w różny sposób. Trudno więc przewidzieć wszystkie możliwe warianty, jakie mogą zaistnieć. Ocena w tym zakresie nie może jednak mieć charakteru dowolnego. Konieczne jest wykazanie w sposób obiektywny związku między aktywnością funkcjonariusza (tj. jego uczestnictwem) a działalnością partii

55 Ustawa o Policji. Komentarz, K. Chałubińska-Jentkiewicz, J. Kurek (red.), Warszawa 2020, Legalis (komentarz do art. 63 ustawy o Policji) - dokonano tu rozróżnienia pojęć: neutralność po lityczna i apolityczność. Przemysław Szustakiewicz wskazuje natomiast, że zakazy ustanowione w pragmatykach służbowych funkcjonariuszy służb mundurowych i żołnierzy zawodowych mają służyć zapewnieniu apolityczności formacji zmilitaryzowanej. Apolityczność rozumie on jako zakaz publicznego manifestowania poglądów politycznych i zakaz kierowania się przy wykonywaniu obowiązków służbowych własnymi przekonaniami politycznymi. Jego zdaniem „apolitycznośc” jest pojęciem szerszym od zakazu przynależności do partii politycznych i oznacza, że osoba pełniąca służbę w formacji zmilitaryzowanej nie wyraża ani nie realizuje w toku służby wyznawanych poglądów politycznych. Ponadto zestawia pojęcie „apolityczność” z pojęciem apartyjność, które utożsamia z zakazem przynależności do stronnictwa politycznego. Zob. P. Szustakiewicz, Stosunki stużbowe funkcjonariuszy stużb mundurowych..., s. 175 i nast. Wojciech Kotowski również stoi na stanowisku, że art. 63 ustawy o Policji odnosi się do apolityczności policjanta. Zob. tenże, Ustawa o Policji..., s. 468. W tym samym duchu wypowiada się Łukasz Czebotar. Zob. tenże i in., Ustawa o Policji..., s. 482. Porównaj także z Leksykonem policyjnym, w którym apolityczność w ujęciu formalnym sprowadzono do zakazu członkostwa funkcjonariusza (policjanta) w partii politycznej, w celu zapewnienia rzetelnego i bezstronnego wykonywania przez niego obowiązków służbowych. Zob. Leksykon policyjny, W. Pływaczewski, G. Kędzierska (red.), Szczytno 2001, s. 23. W tym znaczeniu pojęcie „apolityczność” jest tożsame z pojęciem „neutralność polityczna”. Z kolei w Słowniku wiedzy o Policji wymóg apolityczności policjantów interpretuje się rozszerzająco i obejmuje się nim nie tylko zakaz członkostwa w partii politycznej, lecz także obowiązek poinformowania przełożonego o przynależności do stowarzyszeń krajowych działających poza służbą, a także wymóg zezwolenia przez Komendanta Głównego Policji lub upoważnionego przez niego przełożonego na przynależność do organizacji lub stowarzyszeń zagranicznych albo międzynarodowych. Zob. Słownik wiedzy o Policji, P. Bogdalski, M. Świderski, K.A. Wojtaszczyk (red.), Warszawa 2015, s. 35. 
politycznej lub ustalenie, że taka aktywność (określone działanie) była nakierowana na partię polityczną.

Znajomość granic zakazów wytyczonych przez art. 81 ust. 1 ustawy o ABW oraz AW ma istotne znaczenie dla funkcjonariusza, zakreśla mu bowiem sferę dopuszczalnej aktywności. Pozwala tym samym zarówno na zminimalizowanie prawdopodobieństwa pociągnięcia go do odpowiedzialności dyscyplinarnej, a co za tym idzie możliwości wymierzenia mu kary dyscyplinarnej, jak i ustalenia przesłanki upoważniającej do rozwiązania $\mathrm{z}$ nim stosunku służbowego.

De lege ferenda zasadne wydaje się uzupełnienie regulacji zawartej w ustawie o ABW oraz AW o normę prawną, która skutkowałaby pozbawieniem czynnego funkcjonariusza członkostwa w partii politycznej z mocy samego prawa w momencie zawiązania się stosunku służbowego. Pozwoliłoby to na wykluczenie przypadków naruszenia art. 81 ust. 1 ustawy o ABW oraz AW wynikających z zaniedbania samego funkcjonariusza, który mógł w przeszłości, nawet przez krótki czas, brać czynny udział w działalności określonej partii politycznej, a następnie zaniechał takiej współpracy. W takim przypadku funkcjonariusz może obecnie nie mieć pełnej świadomości, czy formalnie jest członkiem tej partii, gdyż np. zaprzestała ona swojej działalności, ale nie została zlikwidowana, nie została wpisana do właściwej ewidencji bądź niemożliwe jest dotarcie do dokumentacji tej partii lub osób ją tworzących.

\section{Bibliografia}

Chmaj M., Żmigrodzki M., Status prawny partii politycznych w Polsce, Toruń 1995, Wydawnictwo Adam Marszałek.

Czebotar Ł. i in., Ustawa o Policji. Komentarz, Warszawa 2015, Wolters Kluwer.

Dąbrowski M., Konstytucyjny aspekt zrzeszania się cudzoziemców w partiach politycznych w Polsce, „Przegląd Sejmowy” 2011, nr 2, s. 107-124.

Gacek P., Nawiązanie stosunku służbowego z funkcjonariuszem Agencji Bezpieczeństwa Wewnętrznego i Agencji Wywiadu. Charakter prawny mianowania - wybrane aspekty, „Przegląd Bezpieczeństwa Wewnętrznego” 2020, nr 22, s. 98-119.

Gacek P., Wymogi formalne niezbędne do pełnienia służby w Agencji Bezpieczeństwa Wewnętrznego i Agencji Wywiadu - wybrane aspekty, „Przegląd Bezpieczeństwa Wewnętrznego" 2017, nr 17, s. 56-86.

Konstytucja RP. Tom I. Komentarz do art. 1-86, M. Safjan, L. Bosek (red.), Warszawa 2016, C.H. Beck.

Kotowski W., Ustawa o Policji. Komentarz, Warszawa 2008, Wolters Kluwer. 
Kuczyński T., Mazurczak-Jasińska E., Stelina J., Stosunek stużbowy, w: System prawa administracyjnego, t. 11, R. Hauser, Z. Niewiadomski, A. Wróbel (red.), Warszawa 2011, C.H. Beck.

Leksykon policyjny, W. Pływaczewski, G. Kędzierska (red.), Szczytno 2001, WSPol.

Oniszczuk J., Konstytucja Rzeczypospolitej Polskiej w orzecznictwie Trybunału Konstytucyjnego na początku XXI w., Kraków 2004, Wolters Kluwer.

Opaliński B., Rogalski M., Szustakiewicz P., Ustawa o Agencji Bezpieczeństwa Wewnętrznego oraz Agencji Wywiadu. Komentarz, Warszawa 2017, Legalis.

Opaliński B., Szustakiewicz P., Agencja Bezpieczeństwa Wewnętrznego i Agencja Wywiadu, w: Stosunek służbowy w formacjach mundurowych, W. Maciejko, P. Szustakiewicz (red.), Warszawa 2016, Legalis/el.

Opaliński B., Rogalski M., Szustakiewicz P., Ustawa o Straży Granicznej. Komentarz, Warszawa 2019, Legalis.

Prawo administracyjne, J. Boć (red.), wyd. 7, Wrocław 2001, Kolonia Limited.

Prawo administracyjne, E. Ura (red.), Rzeszów 1997, [bw].

Prawo konstytucyjne, P. Tuleja (red.), Warszawa 1995, C.H. Beck.

Prawo konstytucyjne RP, P. Sarnecki (red.), Warszawa 2011, C.H. Beck.

Rogalski M., Szustakiewicz P., Złamańczuk P., Ustawa o Służbie Ochrony Państwa. Komentarz, Warszawa 2019, C.H. Beck.

Skrzydło W., Polskie prawo konstytucyjne, Lublin 1997, Morpol.

Słownik wiedzy o Policji, P. Bogdalski, M. Świderski, K.A. Wojtaszczyk (red.), Warszawa 2015, Aspra.

Sokolewicz W., Partie polityczne w polskim prawie konstytucyjnym: wczoraj, dziś, jutro, „Studia Prawnicze" 1991, z. 4, INP PAN, bez paginacji.

Szustakiewicz P., Stosunki służbowe funkcjonariuszy służb mundurowych i żotnierzy zawodowych jako sprawa administracyjna, Warszawa 2012, Difin.

Ustawa o Krajowej Administracji Skarbowej. Komentarz, L. Bielecki, A. Gorgol (red.), Warszawa 2018, Legalis.

Ustawa o Policji. Komentarz, K. Chałubińska-Jentkiewicz, J. Kurek (red.), Warszawa 2020, Legalis.

Wieczorek M., Charakter prawny stosunków służbowych funkcjonariuszy służb mundurowych, Toruń 2017, Wydawnictwo Adam Marszałek.

Winczorek P., Prawo konstytucyjne Rzeczypospolitej Polskiej, Warszawa 2003, Liber. 


\section{Akty prawne}

Konstytucja Rzeczypospolitej Polskiej z dnia 2 kwietnia 1997 r. uchwalona przez Zgromadzenie Narodowe w dniu 2 kwietnia 1997 r., przyjęta przez Naród $w$ referendum konstytucyjnym $w$ dniu 25 maja 1997 r., podpisana przez Prezydenta Rzeczypospolitej Polskiej w dniu 16 lipca 1997 r. (DzU z 1997 r. nr 78 poz. 483, ze zm.).

Ustawa z dnia z dnia 26 stycznia 2018 r. o Straży Marszałkowskiej (t.j.: DzU z 2019 r. poz. 1940).

Ustawa z dnia 8 grudnia 2017 r. o Stużbie Ochrony Państwa (t.j.: DzU z 2020 r. poz. 384, ze zm.).

Ustawa z dnia 16 listopada 2016 r. o Krajowej Administracji Skarbowej (t.j.: DzU z 2020 r. poz. 505, ze zm.).

Ustawa z dnia 9 kwietnia 2010 r. o Stużbie Więziennej (t.j.: DzU z 2020 r. poz. 848, ze zm.).

Ustawa z dnia 27 sierpnia 2009 r. o Stużbie Celnej (t.j.: DzU z 2016 r. poz. 1799, ze zm.).

Ustawa z dnia 9 czerwca 2006 r. o Centralnym Biurze Antykorupcyjnym (t.j.: DzU z 2019 r. poz. 1921, ze zm.).

Ustawa z dnia 9 czerwca 2006 r. o służbie funkcjonariuszy Służby Kontrwywiadu Wojskowego oraz Stużby Wywiadu Wojskowego (t.j.: DzU z 2020 r. poz. 1221, ze zm.).

Ustawa z dnia 11 września 2003 r. o służbie wojskowej żołnierzy zawodowych (t.j.: DzU z 2020 r. poz. 860 , ze zm.).

Ustawa z dnia 24 maja 2002 r. o Agencji Bezpieczeństwa Wewnętrznego oraz Agencji Wywiadu (t.j.: DzU z 2020 r. poz. 27, ze zm.).

Ustawa z dnia 27 czerwca 1997 r. o partiach politycznych (t.j.: DzU z 2018 r. poz. 580).

Ustawa z dnia 26 kwietnia 1996 r. o Stużbie Więziennej (t.j.: DzU z 2002 r. nr 207 poz. 1761, ze $\mathrm{zm}$.).

Ustawa z dnia 24 sierpnia 1991 r. o Państwowej Straży Pożarnej (t.j.: DzU z 2020 r. poz. 1123, ze zm.).

Ustawa z dnia 6 kwietnia 1990 r. o Policji (t.j.: DzU z 2020 r. poz. 360, ze zm.).

Ustawa z dnia 12 października 1990 r. o Straży Granicznej (t.j.: DzU z 2020 r. poz. 305, ze zm.).

Ustawa z dnia 6 kwietnia 1990 r. o Urzędzie Ochrony Państwa (t.j.: DzU z 1999 r. nr 51 poz. 526).

Ustawa z dnia 30 czerwca 1970 r. o stużbie wojskowej żołnierzy zawodowych (t.j.: DzU z 1997 r. nr 10 poz. 55, ze zm.). 


\title{
Orzecznictwo
}

Wyrok Europejskiego Trybunału Praw Człowieka z 20 V 1999 r., 25390/94, Legalis nr 102542.

Wyrok TK z 10 IV 2002 r., K 26/00. Legalis nr 53826, OTK Seria A 2002, nr 2, poz. 18, DzU z 2002 r. nr 56 poz. 517.

Wyrok TK z 15 IX 1999 r., K 11/99, OTK 1999 r., nr 6, poz. 116, Legalis nr 45366.

Wyrok NSA z 29 I 2020 r., I OSK 3250/18, Legalis nr 2286751.

Wyrok NSA z 16 I 2020 r., I OSK 2949/18, Legalis nr 2282018.

Wyrok NSA z 16 I 2020 r., I OSK 2748/18, Legalis nr 2287530.

Wyrok NSA z 12 VII 2019 r., I OSK 710/17, Legalis nr 2194129.

Wyrok NSA z 18 V 2018 r., I OSK 2439/16, Legalis nr 1837307.

Wyrok NSA z 4 VIII 2017 r., I OSK 1607/16, Legalis nr 1664019.

Wyrok NSA z 8 VI 2017 r., I OSK 656/16, Legalis nr 1632706.

Wyrok NSA z 23 III 2017 r., I OSK 436/16, Legalis nr 1632185.

Wyrok NSA z 18 XII 2014 r., I OSK 611/14, Legalis nr 1330014.

Wyrok NSA z 5 V 2011 r., I OSK 53/11, Legalis nr 352235.

Wyrok WSA w Lublinie z 11 II 2016 r., III SA/Lu 1108/15, Legalis nr 1434512.

\begin{abstract}
Abstrakt
Niniejszy artykuł dotyczy zakazu członkostwa funkcjonariusza Agencji Bezpieczeństwa Wewnętrznego i Agencji Wywiadu w partii politycznej oraz uczestnictwa w działalności tej partii lub na jej rzecz. Zakaz, o którym mowa, został ustanowiony w art. 81 ust. 1 ustawy z 24 maja 2002 r. o Agencji Bezpieczeństwa Wewnętrznego oraz Agencji Wywiadu. Służba publiczna wymaga wprowadzenia pewnych ograniczeń praw funkcjonariuszy w stosunku do reszty członków społeczeństwa. Neutralność polityczna stanowi gwarancję właściwej realizacji zadań i celów wymienionych formacji. W skazano, że przepis art. 81 ust. 1 ustawy o Agencji Bezpieczeństwa Wewnętrznego oraz Agencji Wywiadu zawiera dwie niezależne od siebie normy prawne, tj. zakaz członkostwa w partii politycznej oraz zakaz uczestnictwa w działalności partii politycznej lub na jej rzecz. Uwagę skupiono na wskazaniu granic tych zakazów. W tym aspekcie wytyczono sferę dozwolonego zachowania funkcjonariusza. Podkreślono również, że ograniczenia, o których mowa, nie naruszają praw i wolności zagwarantowanych Konstytucją RP.
\end{abstract}


Słowa kluczowe: służba w ABW lub AW, stosunek służbowy, funkcjonariusz, partia polityczna, zakaz członkostwa w partii politycznej, zakaz uczestnictwa w działalności partii politycznej lub na jej rzecz.

\title{
The prohibition of political party membership and of participation in political party activities or on its behalf imposed on officers of the Internal Security Agency and Foreign Intelligence Agency
}

\begin{abstract}
This paper was entirely devoted to the issues connected with the prohibition of membership in a political party of an officer of the Internal Security Agency and Foreign Intelligence Agency and the participation in the activities of that party or on its behalf. This prohibition was established in Article 81 (1) of the Act of 24 May 2002 of the Internal Security Agency and Foreign Intelligence Agency. Public service requires the introduction of certain restrictions on the rights of officers in relation to the rest of members of society. Political neutrality guarantees proper implementation of the tasks and aims of this formation. There was indicated that aforementioned provision of Article 81 (1) of the Act of 24 May 2002 of the Internal Security Agency and Foreign Intelligence Agency contains two independent legal norms i.e. prohibition of membership in a political party and prohibition of participation in the activities of political party or on its behalf. Attention was therefore focused on indicating the limits of these prohibitions. In this aspect, the sphere of official behavior has been demarcated. There was also underlined that these limits in question do not violate the rights and freedoms guaranteed by the Polish Constitution.
\end{abstract}

Keywords: service in the Internal Security Agency and in the Foreign Intelligence Agency, service relationship, officer, politcal party, prohibition of membership in a political party, prohibition of participation in the activities of political party or on its behalf. 